\title{
The evolution of policy enactment on gender-based violence in schools
}

\author{
Jenny Parkes ${ }^{1}$
}

Published online: 7 July 2016

(C) The Author(s) 2016. This article is published with open access at Springerlink.com

\begin{abstract}
This article examines how policies and strategies to address school-related gender-based violence have evolved since 2000, when gender-based violence within education was largely invisible. Through an exploration of policy enactment in three countries-Liberia, South Africa, and Brazil-it traces remarkable progress in policy, programmes, and research. The analysis asks why, despite such achievements, there is little evidence that these policy enactments have succeeded in reducing violence. The case studies reveal disconnects in the ways violence is conceptualized and acted upon by policy actors, which inhibit effective action. The article concludes that more attention is needed to the 'middle level' space between national and local policy enactments, and to tackling - at national, district, school and community levels - the norms and inequalities at the heart of gender-based violence.
\end{abstract}

Keywords Gender · Violence $\cdot$ Policy $\cdot$ South Africa $\cdot$ Brazil $\cdot$ Liberia

School-related gender-based violence (SRGBV) affects girls and boys across the globe, manifested in physical, sexual, and psychological acts of violence, and underpinned by norms, stereotypes, inequalities, and exclusion. In the twenty-first century, gender-based violence in schools has increasingly come to international attention, with a remarkable growth in research, policy, and practice since 2000. I begin this article by tracing how these developments in educational policies and strategies have come about at an international

This article is based on a background paper commissioned by UNESCO for the Education for All Global Monitoring Report 2015. Thanks to Charlotte Nussey and Cristina Perales Franco for assistance with the case studies.

Jenny Parkes

j.parkes@ioe.ac.uk

1 UCL Institute of Education, 20 Bedford Way, London WC1H 0AL, UK 
level. To investigate important criticisms on the lack of evidence of how to challenge violence, I look closely at policy, practice, and research in three country case studies.

My analysis draws on the concept of "policy enactment", which I use here in preference to "implementation", to signal the importance of multiple actors at national, provincial, district, and local levels, and of contextual dynamics in learning how laws and policies are understood, used, or ignored (Ball, Maguire, and Braun 2012). There is no linear relationship of translation between national laws and policies and the practices concerning gender-based violence in and around schools. Whether and how a teacher adopts a particular policy, for example, is influenced not just by the existence of a law or policy, but also by material conditions and location of the school and by that teacher's professional cultures, values, and experiences (ibid.). A growing literature highlights the gaps between global norms linked to gender, national laws/policies, and local enactments (Eyben 2008; Unterhalter et al. 2008; Wilkie 2012). While policy analyses have tended to focus on national-level policymaking and local-level implementation, a number of recent studies have underlined the significance of policy actors at intermediate levels, including district officials in education, health, and welfare; the police; NGO workers; teacher unions; and teacher-training institutions. Researchers have described this middle-level group as the "missing middle" (Unterhalter 2013), reflecting the lack of attention paid to their role in translating policy into action in schools. Through exploring policy enactments on SRGBV in different country contexts, my aim is to understand what has driven changes in policy enactment, how successful these changes have been, and what else is needed as we move to the post-2015 era.

\section{Global policy evolution since 2000}

Before 2000, SRGBV received very little attention in government policies and plans around the world. In contrast, following the Beijing Platform for Action (1995) and associated campaigns for women's rights, violence against women was firmly on the global policy agenda. Progress occurred in the development of international standards and norms on gender-based violence, including recognition of rape as a tool of war (1998) and the adoption of Security Council Resolution 1325 (2000), which emphasizes the protection of women in conflict situations and their role in peace-building and post-conflict reconstruction. Around this time, campaigns for children's rights met with some success, with the growth of movements to abolish corporal punishment in schools. Moreover, two Optional Protocols to the Convention on the Rights of the Child (CRC), adopted in 2000, provided more detailed protection for children from particular forms of violence-including the sale of children, and child prostitution and pornography - and the rehabilitation of children involved in armed conflict. However, while international treaties like the CRC (1989) and the Convention on the Elimination of All Forms of Discrimination against Women (CEDAW) (1981) prohibit discrimination against girls and provide a mechanism for evaluating countries' compliance, some have said that they pay insufficient attention to gender violence in schools (George 2006).

The disconnects between movements for women's rights and those for children's rights and Education for All (EFA) meant that gender-based violence in schools fell through the policy gap. Although the Dakar Framework for Action (2000) refers to the creation of "safe" learning environments for girls (p. 17), the EFA movement's main concerns in 2000 
were with increasing access to school and with gender parity-gender violence was omitted from its quantitative indicators (George 2006).

Since 2000, policy, research, and action on gender-based violence in schools have markedly increased. The mid-2000s saw the publication of several key reviews, the most influential of which was the UN World Report on Violence Against Children (Pinheiro 2006), which documented that violence against children is a global phenomenon, with most acts carried out by people they know. The report drew attention to everyday physical violence and also psychological violence, including insults and humiliation, neglect, maltreatment, and discrimination. The report saw schools not only as having an important role in protecting children, but also as settings where children may be exposed to corporal punishment, fighting, and bullying (often linked to discrimination associated with poverty, disability, or appearance).

Other reviews published at that time also exposed high levels of violence, and stressed our limited knowledge about patterns of SRGBV. In their review of research evidence worldwide, Dunne, Humphreys, and Leach (2006) noted that much work ignored gender: research in Latin America was concerned with gangs, guns, and drugs; in Asia, with corporal punishment; and in Europe and North America, with bullying by pupils, usually seen in gender-neutral terms. Only research done in Africa had a clearly gendered lensand that work increasingly drew attention to the high prevalence of sexual violence. Dunne, Humphreys, and Leach (ibid.) traced important links with power, emphasizing how unequal gender relations - combined with inequalities based on age, poverty, ethnicity, and sexuality - were frequently at the root of violent acts. They distinguished between explicit gender violence-including overtly sexual acts (sexual harassment, rape, assault, intimidation) - and implicit gender violence, which includes everyday school practices that reinforce gender discrimination and support unsafe contexts for those who do not conform to normative conceptions of masculinity and femininity. Since that time, researchers and practitioners have increasingly used the term "SRGBV" to describe this combination of implicit and explicit gender violence. A later review of policies and programmes at that time similarly highlights the gendered dimensions of much school violence: corporal punishment often more severe for boys, and sexual harassment and violence overwhelmingly experienced by girls at the hands of boys or male teachers (Jones et al. 2008). These analyses signal the importance of viewing acts of violence within gendered and authoritarian school and community cultures.

The growing awareness about violence in schools, stemming from this accumulating body of evidence, has helped to bring SRGBV onto the international policy agenda and had some impact on policymaking at regional and national levels. Following the 2006 report, an Office of the UN Special Representative of the Secretary General on Violence against Children (SRSG) was established to assist governments, international organizations, civil society, and research institutions to work toward ending all forms of violence against children. A number of regions have developed significant initiatives on the abuse and exploitation of children, including the African Charter on the Rights and Welfare of the Child, the Africa Child Policy Forum, the South Asia Initiative to End Violence Against Children (SAIEVAC), and the Keeping Children Safe network of 27 NGOs from Europe, Asia, and Africa. The African Protocol on the Rights of Women (2004) contains provisions to eliminate both marriage under 18 years and female genital mutilation. However, a recent review carried out for UNESCO found that initiatives that specifically address violence in schools are less common (Leach, Dunne, and Salvi 2014). National governments have also begun to strengthen legislative and policy frameworks. The main area of progress is an increase in the number of countries banning corporal punishment, influenced by high- 
profile campaigns like the Global Initiative to End All Corporal Punishment of Children (UN 2011). Governments have passed legislation to make sex with children by teachers and other professionals an offence, and correspondingly to strengthen teachers' codes of conduct (Leach, Dunne, and Salvi 2014).

However, five years after the secretary general's report, the UN Global Update on Violence Against Children presented a depressing picture of very slow progress worldwide (UN 2011). Recent assessments conclude that implementation of SRGBV laws and policies has been patchy, and that our knowledge of what makes programmes successful remains woefully inadequate (Leach, Dunne, and Salvi 2014; UNESCO 2014). These criticisms are directed at research, policy, and practice. Ethical and methodological difficulties have beset research; further, many studies are small-scale and qualitative, making it hard to draw comparisons, generalize, or garner evidence for large-scale programming. While quantitative studies of small-scale programmes have found short-term changes in attitudes and practices, few large-scale or nationally representative surveys of SRGBV - and very few studies-have examined what helps or inhibits policy enactment (UNICEF 2014). Thus, policymakers have insufficient information for building and monitoring SRGBV intervention frameworks. In turn, reviews have criticized policymakers for lack of political will and for fragmented legislative frameworks - creating policies without action plans, training, or resourcing to ensure effective implementation (Leach, Dunne, and Salvi 2014).

At a local level, programmes are often small, piecemeal NGO-led interventions, facing difficulties of sustainability and scale-up. Few robust studies exist of these programmes; many evaluations measure changes in knowledge or attitudes post-training, without assessing whether behaviours have changed or, if so, whether change is maintained over time (Leach, Slade, and Dunne 2012; Lundgren and Amin 2015; Ricardo, Eades, and Barker 2011). Interventions have generally been short term, often addressing one kind of violence, such as corporal punishment, without attending to school cultures, norms, and inequalities (Leach, Dunne, and Salvi 2014).

In this article, I explore these processes of policy enactment using a different approach than these global reviews, focusing instead on three country case studies. I selected these countries-Liberia, Brazil, and South Africa-because of their distinct areas of concern regarding SRGBV. (The original version of this article, commissioned by UNESCO as a background paper for the 2015 EFA Global Monitoring Report [Parkes 2015], included a country case study from India, selected due to concerns about corporal punishment in schools and in order to include a case study from South Asia. I omitted this case study in the present article to strengthen the overall coherence of my analysis and to reduce the article's length. See http://unesdoc.unesco.org/images/0023/002323/232399e.pdf.) These concerns vary relative to these countries' different political, economic, and sociocultural histories.

In Liberia, key issues have related to gender-based violence in the aftermath of conflict. In Brazil, concerns have focused on urban youth violence, including gangs, and violent crime involving boys and young men. While South Africa's recent history includes both of these problems, it has concerns, as well, relating to its very high levels of sexual violence, including rape and intimate partner violence. My intention is to consider whether and how distinct (though overlapping) sets of concerns generate different kinds of interventions in policy and practice.

Examination of the evidence in each country-regarding policy enactment on SRGBV - supports some of the critiques outlined above, but not fully. Somewhat contrary to the criticisms, in these countries there appears to be clear political will to address SRGBV, some impressive local programmes, and a growing body of research that provides 
valuable evidence about the nature of violence. However, two interlinked areas hinder the effectiveness of policy enactments. The first difficulty is conceptual; it relates to a tendency for policy and practice to be reactive rather than preventive. It conceives violence somewhat narrowly, rather than as embedded within social norms and intersecting inequalities. The second related difficulty concerns the lack of evidence about processes of enacting SRGBV policy-in particular, why disconnects exist between national, district, and local levels of policy enactment. Looking closely at these issues in different country contexts generates insights on why it has been so difficult for policy, practice, and research to effectively transform gender-based violence.

\section{Case study: Gender-based violence in post-conflict Liberia}

After 14 years of civil war, Liberia has emerged as one of West Africa's more stable countries. However, the long conflict has left a legacy of high levels of violent crime, large numbers of child soldiers facing unemployment, a patchy infrastructure, and much gender-based violence (Government of Liberia/UN 2011; Vinck and Pham 2013). Though robust data are lacking on gender-based violence in Liberian schools, a number of studies have found disturbing levels of sexual violence and widespread transactional sex involving schoolgirls (Davis 2013; Save the Children 2006). In a recent study of SRGBV in four counties, $30 \%$ of girls and $22 \%$ of boys reported that they had been forced to have sex; and nearly a third of girls and $17 \%$ of boys had been asked for sex in return for money or help (Postmus et al. 2015). Abuse by peers was most common, but almost one in five children spoke of abuse by teachers and other school staff.

The age and power differentials within school classes-due to limited infrastructure, displacement, and many older youths' returning to school after the fighting-may render girls vulnerable to sexual coercion by older young men in school (Davis 2013). In one study with 212 children in urban, semi-rural, and rural districts, almost a third of the children said they had had transactional sex in order to pay for school materials (Antonowicz 2010). In another study, girls in Monrovia said that they exchanged sex for financial rewards, to earn respect, and for grades (Atwood et al. 2011). The power differential makes it extremely difficult to refuse sex.

Contrary to critiques about lack of political will, the postwar government, since its inauguration in 2006, has had gender-based violence firmly on the agenda, spearheaded by President Ellen Johnson-Sirleaf (Government of Liberia/UN 2011). The Liberia National Gender Policy (2009) includes such strategic actions on gender and violence as establishing gender focal points, providing gender and human rights training, enacting and enforcing laws against sexual harassment, increasing the gender capacity, and collecting data on the police (Griffiths and Valasek 2011). The Gender and Sexually Based Violence Act (2008) aimed, through strengthening the criminal justice system and public awareness campaigns, to reduce gender-based violence by $30 \%$ by 2011 (Griffiths and Valasek 2011) — though its action plan paid little attention to schools (UN 2011), and no data collection system is in place to monitor progress at a national level (Davis 2013). The Poverty Reduction Strategy (2008) included prioritizing the security of women and girls, and promoted gender-sensitive curricula of security institutions (Griffiths and Valasek 2011). Liberia's National Action Plan for the Implementation of United Nations Security Council Resolution 1325 (2009) includes outputs and indicators under the four pillars of protection for women: prevention, participation, empowerment, and promotion. However, 
one study found that monthly reporting and monitoring of progress under the plan were not taking place, signaling a continuing need for training at the middle level of policy enactment (Dunne 2011).

While policymakers have responded to gender-based violence against women and girls, they have paid much less attention to preventing violence in school settings. Within education, the emphasis has been on increasing children's access to basic education: Liberia has made considerable progress in increasing school enrolment since 2004, when basic education became free and compulsory and the government cut secondary school fees. At the primary level, the gross enrolment rate is now 94\%, though the gender parity index of 0.75 shows that girls are far less likely to be enrolled than boys (UNESCO 2011). Efforts have been made to increase secondary enrolment - the transition rate to secondary school in 2010 was 62\% (UNESCO 2011) - though competing fiscal demands have hindered implementation of these secondary school initiatives (Atwood et al. 2011). Attempts to increase girls' participation in school have generated policies to protect them from sexual violence by punishing perpetrators (Davis 2013). The 2006 Girls' Education National Policy included objectives to end impunity for SRGBV by teachers. However, it received criticism for stating that teachers who abuse or impregnate girls should be suspended/dismissed "unless they are timely married out of remorse or conscience" and for permitting teachers to return to teaching once their five-year suspensions have ended (Dunne 2011). The 2010-2020 Liberia Education Sector Plan gives the Ministry of Education responsibility for enforcing legal action against teacher and pupil perpetrators of sexual violence, and has developed codes of conduct for teachers.

The policy thrust within education in Liberia has been on gender parity-that is, on increasing the number of girls in school. Gender-based violence in school is thought to hinder girls' access and retention. As seen from the plans mentioned just above, the ensuing policies have been reactive, stressing protection of girls by penalizing offenders. However, few truly preventive policies exist. The limited research traces clear connections between violent practices and social norms that support violence as an expression of masculinity. One study concluded that persistently high levels of domestic violence stemmed from the attempts of men unable to meet rigidly patriarchal societal expectations to reassert power in their households (Government of Liberia/UN 2011). A further study found that $59.2 \%$ of women thought wife-beating could be justified (Davis 2013); in another, $46 \%$ of boys and $34 \%$ of girls agreed that sexual violence was a normal part of relationships between men and women (Postmus et al. 2015). Intersecting inequalities based on gender, poverty, and age appear to be generating high levels of transactional sex, often with much older men-including teachers. Yet there is little evidence of policy attention to how to address these difficult issues about power and to create pedagogies, curricula, and school systems that foster inclusive and equitable beliefs and practices.

The emerging evidence from Liberia shows how, in the aftermath of conflict, poverty and inequitable gender norms combine to create conditions for sexual violence to flourish. Legal frameworks with reporting mechanisms and systems of punishment are welcome, but policies and action plans need to address the ways poverty and gender intersect in shaping violence and discrimination. While the legislative framework indicates the central government's will to reduce gender-based violence, little evidence exists that laws and policies are being implemented or are making an impact in reducing violence. For example, Concern's report "From Incident to Conviction" (2011) compared the four steps in the government's official referral pathway (hospital, police, counsellor, court) to the 27 steps in the unofficial pathways described by education, health, gender, police, and justice officials in Grand Bassa County-demonstrating a clear disjuncture between national and 
local policy actors (Dunne 2011). Rather than navigate these complex pathways, which could take time away from much-needed employment, families tended to settle cases locally (often with financial reparations between families, sometimes involving traditional leaders), and very few cases reached police and judicial services. While the government has used various approaches to support implementation, including media campaigns and a national-level GBV task force, Concern's report adduces little evidence of responsiveness to local conditions and perspectives; the concerns of professionals interviewed centred on how to educate people about violence. The report also voiced apprehensions about the civil war's legacy in terms of the provision of services. For example, it noted the problem of recruiting female police officers because so few women had been able to complete secondary education, and of unrealized plans for building safe houses or criminal courts to address SRGBV outside the capital. Another research study, using data from girls and boys in four counties, pointed out that people's poor access to and mistrust of services such as the police and the judicial system resulted in a "culture of impunity"-in which GBV was disapproved of yet seen as normal, with little expectation that perpetrators would face serious consequences-The study also noted that children frequently did not report violence for fear of being blamed or due to lack of support (Postmus et al. 2015). The study concludes that schools need guidelines and training on how to respond to violence and strengthen the use of their code of conduct (Postmus et al. 2015).

Both these studies raise questions about top-down approaches in policy enactment. Although officials have attempted to coordinate policy activity at the national level, implementation plans lack resources; they also appear not to engage in dialogues with actors at district and local levels, a practice that would help them to understand the norms and practices that perpetuate violence in the legacy of conflict.

\section{Case study: Community violence and schools in Brazil}

Policy on SRGBV in Brazil has followed a very different pathway than in Liberia. In the latter, the EFA drive is a prominent influence, with violence seen as a barrier to schooling; whereas in Brazil, an emphasis on human rights has driven policy, as has a relatively long history of concern about urban youth violence. Children's rights and child protection are enshrined in Brazil's constitution and legal frameworks. In 2014 Brazil became one of a handful of countries prohibiting physical punishment of children in all settings, and several states address bullying through laws and policies. Ranked as one of the most violent countries in the world (Imbusch, Misse, and Carrion 2011), Brazil has given considerable attention to gangs and urban violence; the result is a plethora of community-based programmes. While these programmes can be seen as reactive, in the sense that they are reacting to public concerns about youth violence, they appear to have a strong preventive strand and an awareness of the need to address intersecting inequalities. Community-based programmes like Rotas de Fuga (Escape Routes) and Luta pela Paz (Fight for Peace), for example, adopt holistic approaches that aim to transform youth lifestyles through psychological, professional, academic, and material support (Wilding 2015). Much of this work involves issues relating to masculinity, with boys and young men-particularly in poorer neighbourhoods - considered at high risk of becoming both perpetrators and victims of violence, including extremely high levels of homicide (Barker 2005). Reviews indicate that some of the programmes, like Program $\mathrm{H}$, which aims to help young men question traditional gender norms, have led to shifts in young men's attitudes toward gender (Leach 
2006; Moetsue, Moetsue, and Muggals 2013; Pulerwitz et al. 2006). However, some have criticized the attention to young men-in policy, media, and community programmes-for neglecting the concerns of girls and young women, who are also affected by gang violence in public spaces and domestic violence in the home (Wilding 2015).

Additionally, many have concerns about the government's capacity to maintain law and order and protect its citizens. Reviewing the evidence from violence research in Brazil, Imbusch, Misse, and Carrion (2011) argue that although in recent years improvements have occurred in democratic institutions and civil society engagement, the increasing rates of violent crime undermine democratic processes, particularly in urban centres where poorer young people lack educational and employment opportunities, and where firearms and drugs are easy to procure. Structural inequalities combine with repressive and corrupt policing, and some cities have seen a concomitant growth in violence associated with extra-legal militia. Critics point out the state's inadequate responses to crime, including its failure to reform the police and judicial services, and to provide adequate training for professionals at that intermediate level.

Concerns about peer violence in communities have extended into school spaces, particularly regarding weapons and drugs brought onto school premises, and the effects of community violence on school relationships. The federal government has implemented some large-scale school-based violence-prevention programmes. Since 2004, Escola que Protege (School That Protects) has trained education professionals to prevent, recognize, and mitigate violence involving children and adolescents (Henriques et al. 2007). In an attempt to counter the particularly high levels of violence in urban communities outside school, Escola Alberta (Open School Initiative) combines cultural, artistic, and sport activities with weekend workshops on diversity, rights, and citizenship (Nascimento Tinoco and Alves Silva 2007; UNESCO 2004, 2009). Both projects are government-NGO partnerships and, in the case of Escola Alberta, with UNESCO-Brazil. Qualitative (Aniceto França et al. 2013) and quantitative (Aniceto França et al. 2013; Waiselfisz and Maciel 2013) studies have evaluated Escola Alberta, with positive findings indicating a reduction in some forms of school violence, including threats and theft - though one study raised concerns about whether having the programme on the school premises increased gang presence in schools (Aniceto França et al. 2013).

Until recently, researchers have paid relatively little attention to gender-based violence in Brazilian schools (Morrison, Ellsberg, and Bott 2004), and their findings on this topic have been slim (Ação Educativa 2011). However, several research studies have pointed to ways in which school cultures support discriminatory attitudes and aggression, including homophobic and racist violence and sexual harassment in schools (Carvalho Malta et al. 2010). One study, for example, found that for some boys in urban public schools inflicting physical pain became a code of honour, condoned within the school cultures, and that teachers and pupils commonly had racist attitudes (Abramovay 2006). Conservative forces have resisted attempts to address homophobic bullying through the school curriculum, reportedly hampering these initiatives' capacity to achieve their goals (Diniz Junqueira 2009; Seffner 2013). Slowly, laws on gender equality are being harmonized with education laws and plans; but, while education laws refer to equality, some have criticized them for not being specific on how to address gender equality in the school curriculum (Uriza 2013). The National Plan for Education (2011-2020), however, promotes training on rights and responsibilities, including addressing gender and racial stereotypes in the media.

While violence in public spaces continues to be a major concern in Brazil, influencing policymaking and programmes, these projects illustrate a growing focus on schools as spaces for intervening to prevent violence. As with community-based programmes, the 
concern with youth violence steers attention toward boys and young men, with more consideration needed to address gender-based violence suffered by girls. While policies give some attention to how the curriculum can address diversity issues and some gender issues (especially related to sex education), the need remains to develop sensitive programming that challenges exclusionary and discriminatory perspectives relating to gender and sexuality, to address the ways violence shapes masculine identities, and to promote inclusive school cultures. While the research identifies a number of ways in which the government has attempted to address youth violence and GBV, such as the establishment of women's police stations (Imbusch, Misse, and Carrion 2011), these studies also show weaknesses in the state's capacity to build effective institutions and structures at intermediate and local levels to address violence and related, intersecting inequalities and injustices.

\section{Case study: Sexual violence in schools in South Africa}

Parallels can be drawn between Brazil and South Africa in their policy emphasis on human rights and concerns about very high violence rates. However, South Africa has had a major focus on sexual violence since studies around 2000 documented extensive levels of such violence, including in young people's relationships with intimate partners (Wood, Maforah, and Jewkes 1998) and, in school, by teachers and students (HRW 2001).

The government of South Africa has tried to address this gender-based violence through an impressive legislative and policy framework underpinned by the much-lauded constitution (1996), which enshrines rights to dignity, privacy, and equality; to a basic education; protection for children from maltreatment, neglect, or abuse; to bodily and psychological integrity; and to be free from all forms of violence, whether from public or private sources. With (gender) parity in access to primary and secondary school already achieved by 2000 , South African policy appears to be driven more by human rights and growing concern about levels of violence than by EFA Goal 5. The South African Schools Act (1996) holds that every learner has the right to privacy, respect, and dignity, and that learners are entitled to an environment supportive of education, where there is no violence and no harassment, and where security and freedom of expression are respected. Where a learner has committed an act of sexual violence, such a learner may be suspended. The Employment of Educators Act (1998) enshrined dismissal of teachers for sexual abuse, and the South African Council of Educators (SACE) Act (2000) put in place the Code of Professional Ethics for Teaching Professionals. A period of intense negotiation characterized the democratic transition, in which gender activists helped to shape the democratic discourse as one of rights and equality (Meintjes 2003). Gender violence was a major concern of the Gender Equity Task Team (GETT); its report (1997)—combined with the constitutional mandate to ensure gender equity-led the Department of Education in 2003 to claim that it would take swift action to reduce gender-based violence and harassment in the education system (Chisholm and September 2005).

Programmes and guidance have accompanied the plethora of legislation. These include Guidelines for the Prevention and Management of Sexual Violence and Harassment (2008) in public schools, which sets out a complaints procedure for educators and learners on sexual harassment. More recently, the Department of Basic Education's Handbook for Learners on How to Prevent Sexual Abuse in Public Schools (2010) includes information for students about rights and reporting, and training on bullying in schools has been rolled 
out (Burton and Leoschut 2013). Policies emphasize improvement of pupil safety in schools, using-among other measures_-school safety committees (Mncube and Harber 2013); initiatives to improve lighting, gates, and training in school safety (Geisler, Mokgope, and Svanemyr 2009); and better linkages between schools and police services to improve integrated responses to crime and violence (Burton and Leoschut 2013).

Policy and programming, informed by a strong research evidence base, has given a considerable amount of attention to school violence, yet gender-based violence in South African schools continues to be widespread (Jewkes and Morrell 2012; Mncube and Harber 2013) and policy enactments appear to have done little to counter violence. The difficulties with policy enactment are both practical and conceptual. A recent analysis of sexual violence by educators in Gauteng Province concluded that a crucial reason that such violence persists is the inadequacy of processes and structures to ensure educator accountability (Centre for Applied Legal Studies 2014). At the national level, the report drew attention to inconsistencies in the law. For example, if the Department of Basic Education finds a teacher guilty of a sexual offence but the South Africa Council of Educators does not, the teacher will be dismissed but not struck off the teacher registerand so is free to teach in another school. Schools are not legally required to adopt the national guidelines discussed above, and some schools have not even received them. The report also criticized the biased attitudes, inadequate training, and insufficient resourcing within the judicial system. Researchers have criticized interventions at provincial and school levels as piecemeal and disjointed, with decentralization policies that leave the onus on provincial education systems for implementation (Burton and Leoschut 2013). Teachers and school administrators have been reluctant to report abuse by fellow teachers (Centre for Applied Legal Studies 2014). Research in schools in six provinces found that codes of conduct for teachers in some schools were not visible or used, and that teachers often feared for their own safety because of violence from pupils (Mncube and Harber 2013, p. 28).

These criticisms highlight practical inadequacies of policy enactment in resourcing, training, and building-in mechanisms for accountability relating to SRGBV. There are also important conceptual concerns. A number of South African studies have considered how different beliefs about gender, rights, and violence across South African society may hamper policy enactment. The language of rights and gender equality enshrined in the constitution and legislative frameworks is not shared across the population (Hassim 2009). A study of rural male teachers in Kwazulu-Natal found that age and gender norms intersected in their condoning violence against women and girls, which they viewed as an outcome of threats to masculinity associated with increasing female empowerment (Bhana, de Lange, and Mitchell 2009). Deep-seated beliefs about the necessity of physical punishment for orderly learning and a legacy of authoritarian education practices have led to the persisting use of corporal punishment in schools (Morrell 2001). At the middle level of policy enactment, officials tasked with implementing plans linked to gender and education have tended to view gender narrowly - as numbers of girls/boys enrolled or achieving learning outcomes-thus neglecting girls' experiences of discrimination or violence (Unterhalter 2012). Further, moralistic attitudes of public officials have led to girls being held responsible for "inviting" sexual violence and coercion (Moletsane, Mitchell, and Lewin 2015). Studies with boys and young men have traced how, in contexts of great socioeconomic inequality and social exclusion, violence may become a marker of masculinity, enacted in school through bullying and sexual violence (Bhana 2005; Liang, Flisher, and Lombard 2007). However, some researchers have criticized what they see as overgeneralizing links between masculinity, poverty, and violence, since many boys and 
men in poor neighbourhoods do not support violence (Bennett 2010; De Lannoy and Swartz 2015; Parkes 2007).

Researchers have criticized the top-down nature of policymaking, which has resulted in a language of rights associated with elites and with Western influences (Hassim 2009); yet, others have pointed out that rights are also part and parcel of traditional cultural practices in Africa (Bennett 2010). While a tendency exists to blame traditional beliefs at local levels for the perpetuation of gender-based violence, these studies shift responsibility to policy actors at the middle and upper levels who pay insufficient attention to the inequalities that constrain girls' and women's capacity to act against violence (Moletsane 2005), to the need to support inclusive and well-run schools (Mncube and Harber 2013), and to the critical importance of developing and enacting policy through a broad public, deliberative process (Hassim 2009).

\section{Conclusion: Key priorities for policies related to a post-2015 agenda}

The three country case studies presented here demonstrate a remarkable increase in concern about gender-based violence in and around schools since 2000. Each country has done considerable work in building national legislative and policy frameworks to address forms of violence. Additionally, actors at the local level are making strides in implementing policies to build SRGBV programmes; NGOs often lead this work, though sometimes in collaborations with governments. In the three countries, a growing base of research evidence helps to guide policy enactment. These cases are indicative of a wider global trend in advancing policy and practice on SRGBV - a trend related, in part, to the EFA movement, through which educators have raised concerns about violence as a barrier to girls' participation in education. However, the policy drivers vary; in some countries, as in South Africa and Brazil, it is a human rights agenda, as well as broader concerns about the prevalence of violence, that has provided the impetus to act.

However, the South African case study signals the enormous challenges we face in trying to address SRGBV. Policy enactment is not just about overcoming the practical hurdles of distributing policies and plans, organizing trainings, and strengthening accountability, important as these are. It is about reflecting on our deeply held beliefs and practices, through which we knowingly and unknowingly collude with gender-based violence. Each of the case studies shows how policy implementation on SRGBV requires creating dialogues between the different levels, actors, and institutions involved in creating and putting policies to work. The studies I cite in this article have shown how violence is embedded within everyday interactions, school cultures, and broader political, sociocultural, and economic contexts (Parkes et al. 2013), but they have not paid enough attention to the implications for policy enactment. Nor have they provided the tools for policy actors to use and gather evidence. More work-including the use of local knowledge in policy formulation-is needed on how to address the disconnects in perspectives and practices.

Gender-based violence is now firmly on the international agenda. The Incheon EFA Declaration recognizes "the importance of gender equality in achieving the right to education for all ... supporting gender-sensitive policies, planning and learning environments; mainstreaming gender issues in teacher training and curricula; and eliminating genderbased discrimination and violence in schools" (World Education Forum 2015). The challenge now is for researchers, policymakers, and policy implementors to combine their knowledge more effectively in tackling the deep-seated norms, prejudices, and inequalities 
surrounding violence. The discussions need to involve schools and communities, including young people, their teachers and parents; they must also take place at district, provincial, and national levels of policy enactment. The commitments demonstrated over the past decade provide strong foundations upon which to take action, but only by working at multiple levels can we address the many forms of violence in girls' and boys' everyday lives.

Open Access This article is distributed under the terms of the Creative Commons Attribution 4.0 International License (http://creativecommons.org/licenses/by/4.0/), which permits unrestricted use, distribution, and reproduction in any medium, provided you give appropriate credit to the original author(s) and the source, provide a link to the Creative Commons license, and indicate if changes were made.

\section{References}

Abramovay, M. (2006). Cotidiano das escolas: Entre violências [Violence in primary schools]. Brasília: UNESCO, Observatório de Violência, Ministério da Educação.

Ação Educativa (2011). Informe Brasil: Gênero e educação [Brazil report: Gender and education]. São Paulo: Ação Educativa.

Aniceto França, M., Allon Duenhas, R., \& de Oliveira Gonçalves, F. (2013). Melhoria da qualidade educacional e redução da violência através de abertura de escolas públicas os finais de semana: uma avaliação quantitativa [Improving educational quality and reducing violence by opening public schools at weekends: a quantitative study]. Ensaio: Avaliação de Políticas Públicas em Educação, 21(81), 711-738.

Antonowicz, L. (2010). Too often in silence: A report on school-based violence in West and Central Africa. UNICEF, Plan West Africa, Save the Children Sweden, and Action Aid. http://www.unicef.org/wcaro/ VAC_Report_english.pdf

Atwood, K. A., Kennedy, S. B., Barbu, E. M., Nagbe, W., Seekey, W., Sirleaf, P., et al. (2011). Transactional sex among youths in post-conflict Liberia. Journal of Health, Population and Nutrition, 29(2), 113.

Ball, S., Maguire, M., \& Braun, A. (2012). How schools do policy: Policy enactments in secondary schools. Abingdon: Routledge.

Barker, G. T. (2005). Dying to be men: Youth, masculinity and social exclusion. Abingdon, UK: Routledge.

Bennett, J. (2010). "Circle and circles": Notes on African feminist debates around gender and violence in the 21st century. Feminist Africa, 14, 21-47.

Bhana, D. (2005). Violence and the gendered negotiation of young masculinities in South African schools. In R. Morrell \& L. Ouzgane (Eds.), African Masculinities (pp. 205-220). New York: Palgrave.

Bhana, D., de Lange, N., \& Mitchell, C. (2009). Male teachers talk about gender violence: "Zulu men demand respect". Educational Review, 61(1), 49-62.

Burton, P., \& Leoschut, L. (2013). School violence in South Africa: Results of the 2012 National School Violence Study. Cape Town: Centre for Justice and Crime Prevention.

Carvalho Malta, D., de Souza, E., da Silva, M., dos Santos Silva, C., de Andreazzi, M., Crespo, C., et al. (2010). Vivência de violência entre escolares brasileiros: Resultados da Pesquisa Nacional de Saúde do Escolar (PeNSE) [Experience of violence among Brazilian school children: Results of a National Adolescent School-based Health Survey]. Ciéncia \& Saúde Colectiva, 15(Suppl 2), 3053-3063.

Centre for Applied Legal Studies (2014). Sexual violence by educators in South African schools: Gaps in accountability. Witwatersrand: University of Witwatersrand School of Law and Connell Law School's Avon Global Centre for Women and Justice and International Human Rights Clinic.

Chisholm, L., \& September, J. (2005). Gender equity in South African education 1994-2004: Perspectives from research, government and unions. Cape Town: HSRC Press.

Davis, K. (2013). Sexual violence in Liberian schools. Paper presented at Global Education Leadership Opportunities Conference, Harvard Graduate School of Education, Cambridge, Massachusetts, January 24-25.

De Lannoy, A., \& Swartz, S. (2015). "You don't want to die: You want to reach your goals": Alternative voices among young black men in urban South Africa. In J. Parkes (Ed.), Gender violence in poverty contexts: The educational challenge (pp. 103-117). London: Routledge. 
Diniz Junqueira, R. (2009). Homofobia nas escolas: Um problema de todos [Homophobia in schools: A problem for all]. In R. Diniz Junqueira (Ed.), Sexual na educação: problematizações sobre a homofobia nas escolas. Brasilia: Edições MEC/UNESCO.

Dunne, S. (2011). From incident to conviction: The road to justice. Concern Worldwide Liberia. https:// doj19z5hov92o.cloudfront.net/sites/default/files/resource/2012/11/5877-from_incident_to_conviction_-_ concern_worldwide_report.pdf

Dunne, M., Humphreys, S., \& Leach, F. (2006). Gender violence in schools in the developing world. Gender and Education, 18(1), 75-98.

Eyben, R. (2008). Conceptualising policy practices in researching pathways of women's empowerment. Pathways working paper no 1. Brighton, UK: Institute of Development Studies, University of Sussex. http://r4d.dfid.gov.uk/PDF/Outputs/WomenEmp/Pathways_Working_Paper1.pdf

Geisler, G., Mokgope, K., \& Svanemyr, J. (2009). South Africa: The national gender machinery, gender mainstreaming and the fight against gender-based violence. African Development Bank \& African Development Fund. http://www.afdb.org/en/documents/document/south-africa-the-national-gendermachinery-gender-mainstreaming-and-the-fight-against-gender-based-violence-23016/

George, E. (2006). Failing the future: Development objectives, human rights obligations and gender violence in schools. In F. Leach \& C. Mitchell (Eds.), Combating gender violence in and around schools (pp. 13-22). Stoke-on-Trent: Trentham.

Government of Liberia/UN [Joint Programme on Sexual and Gender Based Violence] (2011). In-depth study on reasons for high incidence of sexual and gender based violence in Liberia: Recommendations on prevention and response. Swedish International Development Cooperation (SIDA). https:// doj19z5hov92o.cloudfront.net/sites/default/files/resource/2012/11/5876-final_high_incidence_of_sgbv_ 15_may.pdf

Griffiths, C., \& Valasek, K. (2011). Liberia. Geneva: DCAF.

Hassim, S. (2009). Democracy's shadows: Sexual rights and gender politics in the rape trial of Jacob Zuma. African Studies, 68(1), 57-77.

Henriques, R., Fialho, L., \& Chamusca, A. (2007). Proteger para educar: A escola articulada com as redes de proteção de crianças e adolescentes [Protect through education: Child and adolescent safety nets in school]. Brasilia: Secad/MEC.

HRW [Human Rights Watch] (2001). Scared at school: Sexual violence against girls in South African schools. New York: Human Rights Watch.

Imbusch, P., Misse, M., \& Carrion, F. (2011). Violence research in Latin America and the Caribbean: A literature review. International Journal of Conflict and Violence, 5(1), 87-154.

Jewkes, R., \& Morrell, R. (2012). Sexuality and the limits of agency among South African teenage women: Theorising femininities and their connections to HIV risk practises. Social Science and Medicine, 74(11), 1729-1737.

Jones, N., Moore, K., Villar-Marquez, E., \& Broadbent, E. (2008). Painful lessons: The politics of preventing sexual violence and bullying at school. Working paper 295. London: Overseas Development Institute.

Leach, F. (2006). Gender violence in schools in the developing world. In F. Leach \& C. Mitchell (Eds.), Combating gender violence in and around schools (pp. 23-30). Stoke-on-Trent: Trentham.

Leach, F., Dunne, M., \& Salvi, F. (2014). School-related gender-based violence: A global review of current issues and approaches in policy, programming and implementation responses to school-related gender-based violence (SRGBV) for the education sector. Paris: UNESCO.

Leach, F., Slade, E., \& Dunne, M. (2012). Desk review for concern: Promising practice in school related gender-based violence prevention and response programming globally. Dublin: Concern Worldwide.

Liang, H., Flisher, A. J., \& Lombard, C. J. (2007). Bullying, violence, and risk behavior in South African school students. Child Abuse \& Neglect, 31(2), 161-171.

Lundgren, R., \& Amin, A. (2015). Addressing intimate partner and sexual violence among adolescents: Emerging evidence of effectiveness. Journal of Adolescent Health, 56, S40-S50.

Meintjes, S. (2003). The politics of engagement: Women transforming the policy process-Domestic violence legislation in South Africa. In A. M. Goetz, \& S. Hassim (Eds.), No shortcuts to power: African women in politics and policy making (pp. 140-159). Chicago: University of Chicago Press.

Mncube, V., \& Harber, C. (2013). The dynamics of violence in schools in South Africa: Report. Muckleneuk, Pretoria: University of South Africa. http://www.unisa.ac.za/contents/colleges/col_education/docs/ The \%20Dynamics\%20of\%20Violence\%20in\%20South\%20African\%20schools.pdf

Moetsue, H., Moetsue, L., \& Muggals, R. (2013). Youth violence prevention in Latin America and the Caribbean: A scoping review of the evidence. NOREF (Norwegian Peacebuilding Resource Centre). http://resourcecentre.savethechildren.se/sites/default/files/documents/muggah-moestue-igarape_noref_ youth-violence-prevention-in-la-and-caribbean_aug-2013_final.pdf 
Moletsane, R. (2005). Looking back, looking forward: Analysing gender equality in South African education 10 years after Beijing. Agenda, 19(64), 80-88.

Moletsane, R., Mitchell, C., \& Lewin, T. (2015). Gender violence, teenage pregnancy and gender equity policy in South Africa: Privileging the voices of women and girls through participatory methods. In J. Parkes (Ed.), Gender violence in poverty contexts: The educational challenge (pp. 183-196). London: Routledge.

Morrell, R. (2001). Corporal punishment in South African schools: A neglected explanation for its existence. South African Journal of Education, 21(4), 292-299.

Morrison, A., Ellsberg, M., \& Bott, S. (2004). Addressing gender-based violence in the Latin America and Caribbean region: A critical review of interventions. Policy research working paper 3438 . Washington, DC: World Bank. http://siteresources.worldbank.org/INTLACREGTOPPOVANA/Resources/ Morrison_Ellsbergh_Bott.pdf

Nascimento Tinoco, A., \& Alves Silva, G. (2007). Programa Escola Aberta [Open School Programme]. Brasilia: Ministério da Educação.

Parkes, J. (2007). Tensions and troubles in young people's talk about safety and danger in a violent neighbourhood. Journal of Youth Studies, 10(1), 117-137.

Parkes, J. (2015). Gender-based violence in education. Background paper for EFA Global Monitoring Report 2015. Paris: UNESCO. http://unesdoc.unesco.org/images/0023/002323/232399e.pdf

Parkes, J., Heslop, J., Oando, S., Sabaa, S., Januario, F., \& Figue, A. (2013). Conceptualizing gender and violence in research: Insights from studies in schools and communities in Kenya, Ghana and Mozambique. International Journal of Educational Development, 33(6), 546-556.

Pinheiro, P. S. (2006). World report on violence against children. United Nations Secretary General's Study on Violence against Children. New York: United Nations.

Postmus, J., Hoge, G., Davis, R., Johnson, L., Koechlein, E., \& Winter, S. (2015). Examining gender-based violence and abuse among Liberian school students in four counties: An exploratory study. Child Abuse and Neglect, 44, 76-86.

Pulerwitz, J., Barker, G., Segundo, M., \& Nascimento, M. (2006). Promoting more gender-equitable norms and behaviours among young men as an HIV/AIDS prevention strategy. Horizons final report. Washington DC: Population Council.

Ricardo, C., Eades, M., \& Barker, G. (2011). Engaging boys and young men in the prevention of sexual violence: A systematic and global review of evaluated interventions. Sexual Violence Research Initiative (hosted by the Medical Research Council, South Africa) for the Oak Foundation. http://www. svri.org/menandboys.pdf

Save the Children (2006). From camp to community: Liberia study on exploitation of children. Save the Children. https://www.essex.ac.uk/armedcon/story_id/000381.pdf

Seffner, F. (2013). "Follow me, the good ones": Trouble and sorrow in confronting heteronormativity in the school environment. Educação e Pesquisa, 39(1), 145-159.

UN (2011). Five years on: A global update on violence against children. Report from the NGO Advisory Council for follow-up to the UN Secretary-General's Study on Violence Against Children. New York: United Nations.

UNESCO (2004). UNESCO's contribution: Empowering youth through national policies. Paris: UNESCO.

UNESCO (2009). Fortaleciendo competencias [Strengthening skills]. Formación continua para el Programa Abriendo Espacios: Educación y Cultura para la Paz. Brasilia: UNESCO.

UNESCO (2011). The hidden crisis: Armed conflict and education. EFA Global Monitoring Report. Paris: UNESCO.

UNESCO (2014). School-related gender-based violence in the Asia-Pacific region. Bangkok: UNESCO.

UNICEF (2014). Hidden in plain sight: A statistical analysis of violence against children. New York: UNICEF.

Unterhalter, E. (2012). Silences, stereotypes and local selection: Negotiating policy and practice to implement the MDGs and EFA. In A. Verger, H. Kosar Altinyelken, \& M. Novelli (Eds.), Global education policy and international development: New agendas, issues and policies (pp. 79-100). London: Continuum.

Unterhalter, E. (2013). Walking backwards into the future: A comparative perspective on education and the post 2015 framework. BAICE Presidential Address, UKFIET Oxford. http://baice.ac.uk/wp-content/ uploads/2013/11/Unterhalter_BAICE-Presidential-Address_Education-post-2015.pdf

Unterhalter, E., North, A., Karlsson, J., Onsongo, J., \& Makinda, H. (2008). Four forms of disconnection: Negotiating gender, education and poverty reduction in Kenya and South Africa. Gender, education and global poverty reduction strategies working paper no. 1. London: Institute of Education.

Uriza, C. M. (2013). La prevención de la violencia contra las mujeres y las niñas desde los marcos legales y enfoques de intervención en los contextos educativos de América Latina y el Caribe [Prevention of 
violence against women and girls through legal frameworks and interventions in educational contexts of Latin America and the Caribbean]. Brasilia: UNICEF.

Vinck, P., \& Pham, P. N. (2013). Association of exposure to intimate-partner physical violence and potentially traumatic war-related events with mental health in Liberia. Social Science \& Medicine, 77, 41-49.

Waiselfisz, J., \& Maciel, M. (2003). Avalação de impacto do Programa Abriendo Espacios no Rio de Janeiro e em Pernambuco [Impact analysis of Open Spaces programme in Rio de Janeiro and Pernambuco]. Brasilia: UNESCO.

Wilding, P. (2015). From assets to actors: Reassessing the integration of girls in anti-gang initiatives in Rio de Janeiro. In J. Parkes (Ed.), Gender violence in poverty contexts: The educational challenge (pp. 153-167). London: Routledge.

Wilkie, M. (2012). Policy enactment in Kenya and Mozambique: Education for pregnant schoolgirls and adolescent mothers. London: Institute of Education.

Wood, K., Maforah, F., \& Jewkes, R. (1998). "He forced me to love him": Putting violence on adolescence sexual health agendas. Social Science and Medicine, 47(2), 233-242.

World Education Forum (2015). Incheon declaration: Education 2030-Towards inclusive and equitable quality education and lifelong learning for all. https://en.unesco.org/world-education-forum2015/incheon-declaration

Jenny Parkes (United Kingdom) is a Reader in Education at UCL Institute of Education, whose research and teaching focuses on education, gender and violence against young people. Her recent book, Gender Violence in Poverty Contexts: The Educational Challenge, won the Jackie Kirk Outstanding Book Award 2016. 